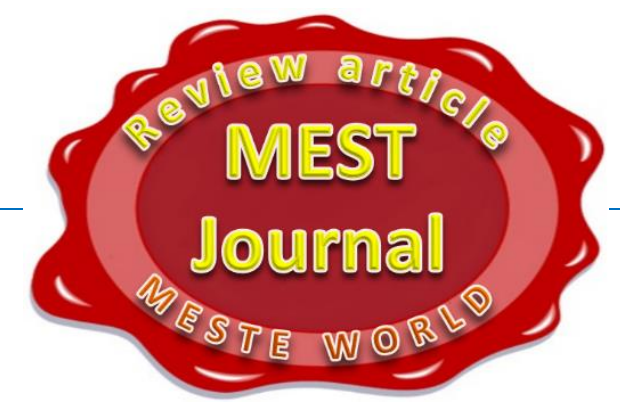

\title{
TRANSFORMATION OF CAREER MANAGEMENT APPROACHES IN THE DIGITAL SOCIETY
}

\author{
Oksana Mineva \\ Astrakhan State University, Astrakhan, Russia
}

Madina Alikaeva

Kabardino-Balkarian State University named after H.M. Berbekov, Nalchik, Russia,

\section{Vladislav Minev \\ Astrakhan State University, Astrakhan, Russia}

OMESTE

JEL Category: J53, M12

\begin{abstract}
The paper deals with the main preconditions for changing the views on the process of career management in modern conditions characterized by the alignment of the traditional hierarchical structure of the company and integration of digital tools into the processes of labor market regulation and company management. Arguments are given in favor of a new approach to considering the process of career management as a process of participatory cooperation of a company (representing the career space), a person (career self-management, through the development of skills, knowledge, and skills necessary for the company), with constant assistance from the state. Recommendations for all subjects of labor relations on the harmonization of career management in modern society have been systematized and given.
\end{abstract}

Keywords: digital society, consciousness change, career management, participatory cooperation, organizational space, management

\section{INTRODUCTION}

Before disclosing the essence of this article, it is necessary to define the terms. The meaning of the very definition of "career" in recent decades is changing rapidly. In traditional notions, a "career" is defined as an employee's vertical advancement

Address of the corresponding author:

Oksana Mineva

㶻okmineva@rambler.ru in his or her career, both within the scope of his or her professional activity and outside it. At the same time, the phrase "to make a career" itself was a priori seen as a vertical growth achieved through a "gentleman's" agreement between the applicant and the company, when, in exchange for the loyalty and efficiency of the employee, the company, for its part, provides him with a guarantee of employment and decent pay, increasing in time. In other words, the main task of career management was to achieve certain stages 
in an employee's working life that would facilitate his or her advancement.

\section{RESEARCH ISSUE}

Today, in the period of the digital transformation of all life processes, change of patterns of behavior of participants of labor relations, change of views on the efficiency of employees and attractiveness of the traditional working schedule, there was a smooth rethinking of the process of career management, the main changes in the environment, the formation of which is presented in Table 1.

Table $1-A$ paradigm shift in career management in the XX-XXI century

\begin{tabular}{|c|c|c|c|c|}
\hline Indicator & $\begin{array}{l}\text { Until the '90s } \\
\text { the twentieth } \\
\text { century }\end{array}$ & $\begin{array}{l}\text { After the '90s } \\
\text { the twentieth century }\end{array}$ & $\begin{array}{l}\text { 2010-2035 } \\
\text { years }\end{array}$ & Moving force \\
\hline $\begin{array}{l}\text { Type of } \\
\text { employment }\end{array}$ & Long-term & Temporary & Temporary & \multirow{4}{*}{$\begin{array}{l}\text { Modification of } \\
\text { economic } \\
\text { situations and } \\
\text { legal norms }\end{array}$} \\
\hline \begin{tabular}{|l|} 
Employment \\
Guarantee
\end{tabular} & Full & Not guaranteed & Not guaranteed & \\
\hline Workplace & Stationary & Stationary & $\begin{array}{l}\text { Stationary } \\
\text { The lack of }\end{array}$ & \\
\hline \begin{tabular}{|l|} 
Working \\
schedule
\end{tabular} & Installed by & Coordinated by & Flexible & \\
\hline Specialization & Narrow & Wide & None & \multirow{3}{*}{$\begin{array}{l}\text { The objective is } \\
\text { to provide } \\
\text { employment }\end{array}$} \\
\hline $\begin{array}{l}\begin{array}{l}\text { Career } \\
\text { development }\end{array} \\
\end{array}$ & Vertical & $\begin{array}{l}\text { Vertical, } \\
\text { horizontal }\end{array}$ & Horizontal & \\
\hline \begin{tabular}{|l|} 
Personnel \\
Development
\end{tabular} & $\begin{array}{l}\text { Employer's } \\
\text { objective }\end{array}$ & $\begin{array}{l}\text { Coordinated task between } \\
\text { employee and employer }\end{array}$ & Employee's task & \\
\hline $\begin{array}{l}\text { The source of } \\
\text { replenishment } \\
\text { of the staff }\end{array}$ & Internal & External and internal & External & \multirow{2}{*}{ Mobility } \\
\hline Staff rotations & Predictable & $\begin{array}{c}\text { Agreed upon by the } \\
\text { parties to the employment } \\
\text { relationship }\end{array}$ & Not predictable & \\
\hline
\end{tabular}

Before discussing the problem of transformation of approaches to career management in the conditions of digitalization, we consider it necessary to give a clear idea of what should be understood by the term "career".

As social relations developed, the meaning of the definition of "career" underwent significant changes. Thus, in traditional notions, a "career" means a vertical promotion of an employee up the career ladder, both within the scope of his professional activity and outside it. At the same time, the phrase "to make a career" itself was a priori regarded as a certain vertical growth achieved through a "gentleman's" agreement between the applicant and the company, when in exchange for the loyalty and efficiency of the employee, the company, for its part, provides him with a guarantee of employment and decent pay, increasing in time. Thus, the main task of career management was to achieve certain stages in an employee's working life that would contribute to his or her advancement.

A change of views on the career management process was facilitated by the international integration of the business, strengthening competition, which required reducing the costs that could be found by changing the view on the traditional bureaucratic model of the company. The pyramidal structure of the company began to level out, absorbing a large layer of "office plankton" - a new competitive structure of the company was dominated by many one- and twolevel structures. At the same time, this led to a sharp status and resource difference between the first and the second tier. Now for "career-building", an employee needs not so much quantitative (length of service in the company, loyalty to the management) as qualitative development, and 
this care within the framework of a new paradigm of views becomes a task of an employee, not of the company. "Career building" for an employee is performed not so much up the career ladder but horizontally, which is career growth. This is exactly what Canter's research has shown (Kanter, 2016) that "instead of predictable progress, modern workers are forced to face the unpredictability of their position. They no longer have the certainty that they will work in the same profession and activity for which they were trained; they cannot be sure of retaining their place in the company, let alone being promoted to new positions and positions. They are offered a variety of alternative employment contracts, and none of them involve full and permanent employment. The main reason for the appearance of such contracts is that they help companies to reduce costs. The only asset of an employee is the ability to choose a job within or outside a company. As they improve their professional skills in the internal and external labor market, they also improve their career opportunities. The middle class now feels as insecure about job security as the working class; their position has become as determined by the unstable and volatile labor market" (Herriot \& Pemberton, 2018, p. 23).

But, at the same time, the career takes an important place in the structure of modern man's needs - the need for self-expression and selfaffirmation (i.e., one of the highest needs according to Maslow A.), thus influencing his satisfaction with work and life in general. A person's desire to anticipate career development with the help of management is also connected with the peculiarities of the Russian mentality - the desire to get everything and, if not at once, as soon as possible.

Each person is free to use his or her labor potential, free to choose the ways of his or her movement in the social structure and social space of society. But it is this freedom that generates competition between people, which poses the problem of each person's competitiveness, achieving personal success against the background of being ahead of others.

This is hugely different from the Asian notion of the professional development of an employee (smooth and long). It is noteworthy that, since 1950, the Japanese have started to implement the idea of Deming W. by motivating and eliminating the fear of being fired. Deming $U$. argued that the fear of losing his job prevents sincere communication and the desire to work well and blocks creativity. The Japanese applied these ideas in the post-war years by introducing a system of lifelong employment. The lifetime employment system covers about $35 \%$ of Japan's labor force employed in large companies and government institutions, which is one of the most important driving forces in the labor sphere, as shown in Table 1 (Bettli, 2007, p. 143).

Table 2 shows the main differences between the European and Asian approaches to human resources management, examining which we can see the smooth "expansion" of Asian approaches in the practice of European countries and Russia.

Table 2 The dualism of traditional approaches and the impact of digitalization during the personnel management process

\begin{tabular}{|c|c|c|}
\hline European & Asian & Digital \\
\hline $\begin{array}{l}\text { For any task, you can find a } \\
\text { person who exactly meets the } \\
\text { requirements of the position and } \\
\text { the requirements of the social } \\
\text { system. }\end{array}$ & $\begin{array}{l}\text { Everyone can be trained and } \\
\text { precisely tuned to the right wave, } \\
\text { to the requirements of the social } \\
\text { system. }\end{array}$ & $\begin{array}{l}\text { Everyone must be prepared to } \\
\text { work under the proposed } \\
\text { conditions from the outset. }\end{array}$ \\
\hline $\begin{array}{l}\text { You cannot change people; you } \\
\text { can only replace them with } \\
\text { others. Their qualifications and } \\
\text { connections - everything can be } \\
\text { restored by selecting the right } \\
\text { people for the job. }\end{array}$ & $\begin{array}{l}\text { You do not have to look for the } \\
\text { perfect people. The most } \\
\text { effective and reliable thing is to } \\
\text { train and tune those who already } \\
\text { work. }\end{array}$ & $\begin{array}{l}\text { In the age of digitalization in } \\
\text { the world of the Internet, you } \\
\text { can always find the most } \\
\text { appropriate. }\end{array}$ \\
\hline $\begin{array}{l}\text { There are no irreplaceable } \\
\text { employees. }\end{array}$ & No untrained & Perfect employees are \\
\hline
\end{tabular}




\begin{tabular}{|c|c|c|}
\hline European & Asian & Digital \\
\hline $\begin{array}{l}\text { What are the criteria for } \\
\text { selection? } \\
\text { On what categories, qualities, } \\
\text { formal attributes to rely on? } \\
\text { What methods to diagnose and } \\
\text { evaluate? }\end{array}$ & $\begin{array}{l}\text { Teach what? } \\
\text { What do you set it up for? } \\
\text { What methods to tune, motivate, } \\
\text { stimulate? }\end{array}$ & $\begin{array}{l}\text { What is the level of } \\
\text { remuneration to motivate? }\end{array}$ \\
\hline Short-term employment & Lifetime employment & One-time recruitment \\
\hline Staff rotation system & $\begin{array}{l}\text { Gradual, slow assessment and } \\
\text { promotion }\end{array}$ & $\begin{array}{l}\text { Lack of guaranteed staff } \\
\text { rotation }\end{array}$ \\
\hline Specialized activity & Unspecialized activities & Polyvariate activity \\
\hline Quantitative control mechanisms & Informal mechanisms of control & Quality control mechanisms \\
\hline Individual decision making & Collective decision making & External control \\
\hline Individual responsibility & Collective responsibility & Individual responsibility \\
\hline $\begin{array}{l}\text { The secondary importance of } \\
\text { using the human factor in } \\
\text { governance }\end{array}$ & $\begin{array}{l}\text { Primordial attention to the use of } \\
\text { the human factor in management }\end{array}$ & $\begin{array}{l}\text { The secondary importance of } \\
\text { using the human factor in } \\
\text { governance }\end{array}$ \\
\hline
\end{tabular}

The essence of the Asian system of personnel rotation is that the recruitment of the workforce is carried out once a year and coincides with the mass graduation of young specialists from educational institutions. Promotion is carried out only among persons who have worked in the company for a long time. For the first time, young employees are rotated ten years after they joined the company. All this does not contribute to the promotion of personal ambitious projects by young employees who are of immediate importance for the company, as in the future these projects may not only lose their importance but even bring losses to the company. By doing so, Japanese managers demotivate young employees to "support" their older colleagues and cultivate in them a trusting attitude to the elders, which is developed through the mechanism of group decision making (so-called rings). Group responsibility for solving a set of company's tasks is one of the keys to the success of Japanese companies (Ouchi, 1984, p. 184). In many respects thanks to it Japan today is a part of a world technological core (Lipsits \& Neshchadin, 2017).

Hiring in European companies is usually shortterm. Annual turnover can reach $50 \%$ of technical and clerical staff and up to $25 \%$ of senior staff. In response to high turnover, European companies employ rapid assessment and rapid promotion mechanisms. Naturally, with such turnover, a career that can be built is deeply specialized. Specialists name high career specialization as one of the reasons for high turnover in European companies, which carries with it the monotony of work, provoking the staff to seek diversity on the side.

The question arises, why then should modern European managers manage the career of their employees? The answer is obvious: managers are always focused on making full use of the potential of their employees, and the motivation for "career development" is unusually attractive to the employee. At the same time, employees are habitually oriented towards professional and job requirements, but the main reference points for them, as a rule, are time indicators: the speed and pace of job growth in the company, managerial age, which allows correlating the degree of progress in the hierarchy of the management system and the age of the applicant.

It is also impossible to bypass the issue of forming the organizational space of the company. The goal of the employee is socialization in the organizational space, while the company's goal is to preserve the integrity of this space, which is especially important for its professional and jobrelated component.

Traditional career management was a process of professional, personal, social development of a person, expressed in his or her advancement in 
positions, qualifications, statuses, accompanying resource support for the expansion of the company's organizational space, or the development of social space (inter-organizational career). Career management touched upon such important factors as staff satisfaction with work in the company and related productivity and loyalty; continuity of professional experience and company culture; ensuring necessary and rational replacement of key positions; an internal increase of implicit knowledge of the company and growth of its competitiveness in the market.

In modern conditions, when not only the flattening of organizational structures affects the formation of personnel policy, but the whole range of digital tools, career management issues become a personal matter for most hired employees.

It should be noted that through career management issues the state has traditionally solved the problems of satisfaction with growth and development in the work of its citizens, which had an impact on reducing or increasing social tension in society, and the professional potential of each - on the dynamism and quality of economic and administrative reforms as a whole.

That is why, in the digital age, the state cannot allow self-management of careers and transfer of all responsibility to the level of each employee.

Career management in the digital age should be a participatory process of cooperation between the company (representing the career space), the employee (self-management of the career, through the development of competencies necessary for the company), with constant assistance in the field of employment and retraining from the state.

Let us consider the main stages of managing an employee's career in a modern company, which represents a systemic unity of company and employee.

Using the methodology of modern management, we will divide all stages of career development management into strategic, operational, and tactical.

\subsection{Strategic stage of career choice.}

Career strategy is very dynamic, as it is influenced by many different factors - mainly the market, changes in which conditions have a great influence on professional preferences and final career goals. The demand for different professions passes the test of time and does not always stand it. Saturation of the labor market with individual professions reduces the demand for them, "slows down" career expectations, while the demand is cyclical. The accuracy of forecasting trends in the development of the labor market and society directly affects the success of a career strategy. Special attention should be paid today to the Atlas of Future Professions, which require knowledge in the field of high technology and artificial intelligence. Modern HR-specialists believe that in the new digital labor market professional competencies will be replaced by sub-professional competencies, which will include effective communication and teamwork skills, knowledge of the foreign language, and robotics. Approximately $35 \%$ of basic skills will not be in demand in the new labor market.

Therefore, when building a career strategy, it is important to decide on the following positions, namely:

- how much the selected professional profile is in demand on the labor market (level of competition among the owners of this profile). the extent to which the chosen profession is opportunistic/status in the society.

- what other career paths/profiles adjoin the given profession, what are the requirements for additional education.

- which job position is the limit for the development of this specialization in the market/company.

- the extent to which the chosen professional profile depends on the specifics of the regional market (monocity).

If there are answers to these questions, and they allow one to conclude that the desired profile will allow to adequately self-realize, then this point is the starting point for the formation of a future career profile, which depends largely on the literacy of the person and often his parents. The company's influence at this stage arises only in two cases - in case of payment for the training of own employees, or in case of access of parents of a potential employee to informal power resources of the company, through payment for target contract training of a future employee in a higher education institution.

Evidence of the need to identify patterns in strategic career planning is provided by a study 
showing that $23 \%$ of MBA students experienced significant career failures early in their careers (e.g. a period of inactivity of more than one month) and $13 \%$ experienced mid-career breakdowns (Schneer \& Reitman, 1994).

\subsection{The operational phase of career development}

Despite the large number of random factors affecting the process of career management, it is worth trying to identify the main desired goals and set a sequence of actions to achieve them. This is the moment when both the employee and the company become full partners. In contrast to the past views, when the process of career building was considered by a person as a continuous action, continuing throughout professional life, today it is more appropriate to consider this process as a sequence of projects, that is, actions with a certain result, limited in time and resources.

It is known from management theory that it is always necessary to define a foreseeable goal for the foreseeable period, with tangible control points. Psychologists advise young specialists to go from the opposite - not who I would like to become within the professional trajectory of growth, and whoever I would not like to become. That is to define the specialties adjoining to the received professional field which are not the desirable object of a career soon. Today, most people proceed in their daily life from the following - they earn their living in one way, but selfactualization is provided differently - through hobbies, through non-commercial activity.

Having control points of future career development, it is necessary to pass to the definition of a logical sequence of the decision of a series of problems leading to career building. To take into account all the possible tasks that will need to be solved, it is better to conduct a small brainstorming session, gathering various participants who can "throw" a large number of steps required for the successful course of a career - and this, of course, is the company's task. Each of the tasks should be linked to the terms, conditions, and resources needed to complete the task.

The final document at this stage is an optimized career plan, which represents a real logical sequence of tasks and actions to implement them, considering the available resources and time constraints and opportunities.
Then we should proceed to direct implementation.

During execution, it is necessary to outline certain "reconciliation points" - usually they are bound to time. For example, once a month we look at all the achieved results, compare them with the tasks, perform analysis of actions, choose the most effective ones, and refuse from others.

Also, career management should pay attention to career risks, which include social risks; resource risks; and natural risks.

Social risks are heterogeneous, including social origin, gender, race, religion, educational demand, and the economic situation of the educational institution, the lack of necessary connections among those in power, disability since childhood, or sexual orientation. Social risks are risks related to an individual's origin, inherited and acquired social and property status, and personal and physiological characteristics. The presence of social risk does not mean that the development of a successful career will be impossible, but that a separate resource must be put in place to overcome the consequences of risk.

Resource risks are the degree of control over the resources needed to build a career, which largely determines a person's freedom to build their career. The initial stages of career-building usually require serious investment, and they begin to generate income after a long time.

Natural risks - the impact of factors beyond the control of the will of the person building his or her career: changes in market conditions, a ruin of the company, critical changes in legislation (political orientation) by the state and fiscal authorities, the collapse of the socio-economic formation, war, earthquake, flood and so on. Natural risks do not lend themselves to adequate forecasting when planning a career project, so their overcoming is connected, as a rule, with the beginning of building a new career.

Well-known researchers Buckingham and Coffman, who conducted several decades of research by the Gallup Institute on management efficiency, including career-building by internationally recognized successful managers, advise to remember six key issues at the initial stage of career building and listen to the following advice (Bakingem \& Koffman, 2019, p. 123):

- Do I know what is expected of me at work? 
- Do I have the materials and equipment that I need to do my job properly?

- Do I have the opportunity at work to do what I do best every day?

- Have I received appreciation or approval for a job well done in the last seven days?

- Do I feel that my immediate supervisor or someone else at work is taking care of me as a person?

- Do I have someone at work who encourages my growth?

These questions include details that are important for my role as a "catalyst". To achieve positive answers, the manager must perfectly fulfill four tasks: to choose the person, to formulate a "package of expectations", to stimulate and develop.

To select a person, to formulate his expectations from his work, to stimulate him, and to promote his career development - these are the four main components of the manager's role as a "catalyst", as a provider of the company.

At first glance, it seems to be the right advice. Many companies are guided by them. However, these tips miss the point. You will not create a great team by simply hiring people based on their experience, intelligence, and willpower. By observing the sequence of actions and working on the shortcomings of your employees, you are unlikely to ensure consistently high results. And preparing an employee for the next step of the ladder does not mean development at all.

Buckingham M. and Coffman K. rightly conclude that:

- employees should be selected based on their abilities, not just experience, mind, or willpower.

- When formulating expectations, it is necessary to clearly define the desired result, not to describe the work step by step.

- While stimulating the subordinate, we should focus on his or her strengths, not on his or her weaknesses.

- a person should be developed, helping him/her to find his/her place, not to climb the next step of the service ladder (Bakingem \& Koffman, 2019, p. 23).
When forming an employee's career development strategy, it is particularly important to consider some psychological phenomena of "carte blanche" and "cooling". Usually, an employee who comes to the company or goes up the career ladder has a kind of "carte blanche" for the period from 3 months to half a year (the higher the post, the longer the period) for self-realization from the management. During this period, the employee pays $100 \%$, regardless of some "cold" of the team, which arises because they managed to get used to it but did not have time to be accepted as "their". In response to this "coldness", the employee "cools down" himself. If during this period the employee can force himself to invest almost $100 \%$, then the period of "carte blanche" will return, but with a shorter duration. And so, it will be until the company begins to react confidently to him as its "own". The period of equalizing the attitude to the employee is directly proportional to the level of his authority: the more authority, the longer this period is. Sometimes an employee may make an emotionally wrong decision to leave the company at the stage of "cooling down" to himself.

\section{CONCLUSIONS}

Since the satisfaction of employees with their work (including career advancement) is one of the factors to increase the competitiveness of the company, a career management system is necessary.

Such a system should apply to all employees holding (or applying for) management positions, not only those selected for the personnel reserve.

The career management system should be based on an analysis of work and competency models for each organizational level, which is increasingly fragmented.

If the career management system functions correctly, employees share responsibility for their development and are sufficiently motivated. Employees should be aware that their career is in their own hands and depends on their efforts.

The Company opens new ways for them and must provide them with resources (possibly on cofinancing terms).

\section{WORKS CITED}

Bakingem, M., \& Koffman, K. (2019). Snachala narush'te vse pravila. Chto luchshiye v mire menedzhery delayut po-drugomu. Seriya Must Read. Moscow: Al'pina Pablisher. 
Bettli, S. (2007). Trener dlya rukovoditelya. Kak dobit'sya ekstraordinarnykh rezul'tatov blagodarya kouch-menedzhmentu. Moscow: Balans Biznes Buks.

Herriot, P., \& Pemberton, C. (2018, June). Contracting Careers. Human Relations, 49(6), 757-790. doi:10.1177/001872679604900603

Lipsits, I., \& Neshchadin, A. (2017). Promyshlennaya politika Rossii: printsipy formirovaniya i mekhanizmy realizatsii. Obshchestvo i ekonomika(5), 28.

Ouchi, U. (1984). Metody organizatsii proizvodstva. Yaponskiy i amerikanskiy podkhody. Moscow: Ekonomika.

Schneer, J. A., \& Reitman, F. (1994). The importance of gender in mid-career: A longitudinal study of MBAs. Journal of Organizational Behavior, 15(3), 199 - 207.

Received for publication: $\quad 09.01 .2020$

Revision received: $\quad 22.04 .2020$

Accepted for publication: $\quad 01.07 .2020$

\section{How to cite this article?}

Style - APA Sixth Edition:

Mineva, O., Alikaeva, M., \& Minev, V. (2020, July 15). Transformation of career management approaches in the digital society. (Z. Cekerevac, Ed.) MEST Journal, 8(2), 143-150. doi:10.12709/mest.08.08.02.16

Style - Chicago Sixteenth Edition:

Mineva, Oksana, Madina Alikaeva, and Vladislav Minev. 2020. "Transformation of career management approaches in the digital society." Edited by Zoran Cekerevac. MEST Journal (MESTE) 8 (2): 143-150. doi:10.12709/mest.08.08.02.16.

Style - GOST Name Sort:

Mineva Oksana, Alikaeva Madina and Minev Vladislav Transformation of career management approaches in the digital society [Journal] // MEST Journal / ed. Cekerevac Zoran. - Belgrade Toronto : MESTE, July 15, 2020. - 2 : Vol. 8. - pp. 143-150.

Style - Harvard Anglia:

Mineva, O., Alikaeva, M. \& Minev, V., 2020. Transformation of career management approaches in the digital society. MEST Journal, 15 July, 8(2), pp. 143-150.

Style - ISO 690 Numerical Reference:

Transformation of career management approaches in the digital society. Mineva, Oksana, Alikaeva, Madina and Minev, Vladislav. [ed.] Zoran Cekerevac. 2, Belgrade - Toronto : MESTE, July 15, 2020, MEST Journal, Vol. 8, pp. 143-150. 